\title{
A FRAMEWORK FOR AN INDUSTRIAL ENGINEERING LEARNING FACILITY PARADIGM TOWARD INDUSTRY 4.0
}

\author{
S.M. Sackey ${ }^{1 *}$, A. Bester ${ }^{2} \&$ D.Q. Adams ${ }^{2}$
}

\section{ARTICLE INFO}

\section{Article details}

Submitted by authors

1 Jul 2017

Accepted for publication

Available online

\section{Contact details}

* Corresponding author smsackey.coe@knust.edu.gh

Author affiliations

1 Department of Mechanical Engineering, Kwame Nkrumah University of Science and Technology, Ghana

2 Department of Systems and Industrial Engineering, Cape Peninsula University of Technology, South Africa
As the industrial world inches ever closer to adopting the Industry 4.0 paradigm, it becomes necessary to evolve a model industrial engineering (IE) learning facility framework that is comprehensive enough to accommodate the full range of exposures required to give students a total practical learning experience. This paper formulates a description model (morphology) and classification scheme for an IE learning facility that considers various levels of automation, including Industry 4.0, to support holistic IE education and training in South Africa. The literature is searched to investigate the state of the art in IE practical learning infrastructure. A questionnaire survey then determines the current status and practices among universities offering industrial engineering. This is followed by the construction of a learning facility framework embodying a mix of facility types, along with a delineation of their relevant characteristics, niches, and strengths that can be customised and deployed to maximise the practical experiences of students.

\section{OPSOMMING}

Soos die industriële wêreld nader aan die aanvaarding van die Industrie 4.0 paradigma beweeg, raak dit nodig om 'n model raamwerk vir bedryfsingenieurswese $(\mathrm{BI})$ te ontwikkel, wat oorkoepelende blootstelling aan studente verleen om ' $n$ wye spektrum van praktiese leer te ervaar. Hierdie artikel formuleer ' $n$ beskrywende model (morfologie) en ' $n$ klassifikasie skema aan 'n BI leerfasiliteit wat verskillende vlakke van outomatisasie, insluitende Industrie 4.0, oorweeg, om die holistiese $\mathrm{BI}$ opvoeding en opleiding in Suid-Afrika te ondersteun. Die literatuur word bestudeer om te soek na die hoogste vlak van BI praktiese opvoedingsinfrastruktuur. Dan word ' $n$ vraelys gebruik om te bepaal wat die toestand, en praktyke by universiteite wat $\mathrm{BI}$ aanbied, is. Daarna volg die ontwikkeling van 'n leerfasiliteitraamwerk, wat al die tipe fasiliteite met inagneming van die relevante karakteristieke, spesialis eienskappe, en sterkpunte insluit om die praktiese ondervinding van die student tot $n$ maksimum te benut.

\section{INTRODUCTION}

\subsection{Industrial engineering education support infrastructure in Industry $\mathbf{4 . 0}$}

Technology is, without a doubt, playing a critical role in how engineering curricula are being developed and implemented. To meet the challenges associated with the increasing digitisation and complexity of industrial systems, a greater degree of flexibility and scope is needed in the industrial engineering practical teaching and learning facilities that are required to ensure holistic learning by students. Innovative learning environments are required that can react quickly and flexibly to the fluid nature of today's industrial environments. The intent of this paper is to develop a comprehensive framework, in a South African context, that embodies different dimensions of a learning facility, from manual labs to Industry 4.0 learning factories, as a basis on which a learning facility mix strategy can be built. The objective is to provide a platform to evaluate the role and strengths of each learning facility so that alternatives can be compared and choices made to formulate and adopt a strategy. 
A 'learning facility' is any infrastructural environment or setting such as a laboratory, physical or virtual; a learning factory, physical or virtual; or a real factory - that is, a setting other than a place for purely theoretical classroom instruction, where students spend time using the facility to study, learn under (or without) guidance, or investigate a concept.

Industry 4.0 is a collective term for technologies and concepts of a value chain organisation that draws together cyber-physical systems, the Internet of Things, and the Internet of Services [1, 2]. In Industry 4.0, cyber-physical systems made up of connected systems of software, sensors, machines, workpieces, and communication technologies monitor physical processes, create a virtual copy of the physical world, and make decentralised decisions. This is all done while communicating with each another, with humans, and with centralised controllers in real time as products travel through the production system $[3,4,5,6]$.

The very nature of Industry 4.0, and the relatively slow pace of South African industry in responding to new world trends and paradigms, means the journey to full-blown Industry 4.0 could be long. This calls for a 'road map' framework embodying, at any time, a balanced mix of progressively upgradable and practically oriented facilities geared toward Industry 4.0 or some other similar ideal. The level of interdisciplinary training required today demands an ideal format for meeting these needs, necessitating teaching and learning approaches that take account of the complexity of real-world manufacturing systems to evolve realistic learning environments that bring student experiences closer to real practice [7]. The fast pace of technological change, and the resource challenges it imposes, also mean that flexible facilities are needed that can accommodate a wider variety of scenarios for longer periods of time. Motivations for this study thus include the following:

1. As the cost of creating new specialised labs to match the ever-changing industrial (digital) environment becomes prohibitive, a need arises to develop a strategy that assures efficiency in the use of scarce resources.

2. As the functions and research areas of IE expand beyond traditional boundaries, it becomes paramount to strategise the efficient use of resources.

3. The misgivings of some institutions (due to cost constraints) to take up new concepts and technologies such as Industry 4.0 learning systems [8] mean that a full case must be made in outlining the place and benefits of each component in the full complement of facilities needed in the learning support infrastructure.

4. The ever-growing complement of required facilities means that guidance is needed in formulating a selection strategy to suit needs, and in defining a viable path toward Industry 4.0. While this may not be a serious problem for well-endowed institutions, it is serious for those that do not have the means to acquire every state-of-the-art facility quickly.

5. Frustration caused by rapid technological change, which tends to render new facilities outdated far sooner than expected, may have played a role in some institutions losing interest in maintaining their physical facilities.

Since Industry 4.0 , and by extension the Industry 4.0 learning factory concept, is in its seminal stages of development, it is essential to define clearly the structure and methodology of a framework strategy to guide the path, rapid or slow, to its implementation in IE departments. However, there is little or nothing in the literature about a comprehensive morphology of practical learning infrastructure that undergirds theoretical instruction in a holistic way. To address this gap, this work proposes a unified framework as the basis for a generic learning facility strategy to support IE education. Clearly its promise lies in its potential to advance knowledge about the place and growing importance of learning facilities in IE education, and of the paths and factors to be considered when choosing between learning facility options.

\subsection{Overall research approach}

The steps taken in executing this work include a literature review, data collection via a questionnaire from universities offering industrial engineering, an analysis, and the conceptual modelling of the IE facility framework. This approach promises to be effective in evolving a framework that is comprehensive enough to address a wide range of scenarios.

In the next section, the approach and rationale for the study are detailed, followed in Section 3 by a review of the relevant literature. Section 4 focuses on the conceptual design of the learning facility framework and the presentation of the survey results, while Section 5 discusses the model and other results and findings from the study. Section 6 closes the study with an elaboration on the conclusions drawn, and hints at the future direction of research towards an even more fully integrated and holistic IE education. 


\subsection{Aim, scope, and research questions}

The aim of the study was to evolve a framework for an industrial engineering practical learning infrastructure that embodies various levels of facility automation, up to and including Industry 4.0 systems. This is done first by identifying the role, potential contributions, and strengths of each component facility in the total space.

\subsection{Design of the research}

The research methodology was to review the literature and conduct a survey by sending out questionnaires to all the universities that offer industrial engineering in South Africa, focusing on their existing infrastructure. The literature search involved determining the state of the art in IE practical learning requirements in relation to IE learning support infrastructure. The literature on IE physical and virtual learning factories was reviewed. From these data, a learning facility morphology framework was designed, tested, and validated.

The initial research questions that guided the literature search included the following:

1. What kind and mix of industrial engineering education learning facilities are required to give students holistic practical instruction?

2. How will the emerging dimensions of IE in Industry 4.0 and relevant changes on the industrial shop floor influence or inform the design of a strategy for choosing a learning facility mix?

3. What key aspects of IE knowledge are best taught or demonstrated with support from which infrastructure type? And with what justification?

The outcome of the literature search was a set of pointers indicative of the dimensions of a learning facility infrastructure that is suited to industrial engineering education. These then formed the basis of a survey of IE programmes to determine what fundamental practical learning facilities each institution already had in place.

\subsection{Search and data gathering strategies}

In the data-gathering process, relevant sources and key words were first identified. These included journals, conference proceedings, technical reports, articles from trade journals, and lab equipment company websites. Phrases and keywords that could be relevant to engineering education labs and learning factories and their potential impacts on IE instruction were employed in the search - for example, industrial engineering lab, virtual lab, and learning factory. The word lab was sometimes combined with industrial engineering, learning factory, smart factory, and virtual in the search. The search also included a significant number of non-journal internet sources. In the next and last phase of the data collection process, a questionnaire was administered to relevant universities to determine their current status, practices, and future plans relating to the practical aspects of IE learning support infrastructure. The developed questionnaire, based on findings from the literature, was distributed to all ten industrial engineering programmes in South African universities, both traditional and technical. It sought to gather information about the level of practical learning infrastructure development and any relevant actions being taken in IE departments with regard to emerging trends. The response rate was 90 per cent. Data was mostly collected online, but also by telephone. The questions for this secondary data collection exercise included:

1. Does your IE department have a production systems (PS) lab?

2. If yes, is it modular, flexible, or reconfigurable, or fixed in structure?

3. If no, what are your alternatives or reasons?

Questions covering current and future learning factory deployment in IE programmes in South Africa have already been dealt with in a previous study [8].

Responses to the questions above helped to form an overall picture of the status and future plans relating to learning facilities, and to model a generic learning facility framework.

\subsection{Results, analysis, modelling, and presentation of concepts}

The data gathered were analysed to identify trends, patterns, and features of practical instruction infrastructure in the world and, among South African universities in particular, about the development of such facilities. Analysis of the data focused on the practical demonstration of core IE functions and 
concepts, and on the use of learning facilities to model, mimic, and optimise industrial systems for student education and training. Last, the framework and its parameters were conceptualised and analysed.

\section{LITERATURE REVIEW}

Recent research [7] [10] has shown that the ever-increasing complexity of industrial systems makes interdisciplinary courses necessary if students are to integrate information technology (IT) and industrial engineering into new formats for teaching and learning, which include a wide range of practical teaching and learning support systems such as factories of learning [6]. Schuster, Groß, Vossen, Richert and Jeschke [7] have highlighted the enormous losses usually associated with transferring externally learned content to the requirements of the workplace.

Few previous works in the literature address IE learning facilities in a holistic way. However the literature on emerging paradigms such as Industry 4.0 learning factories is steadily building up. Aside from a manual production system laboratory and its focus on building the specific capabilities required in low-automation environments, IE learning facility models found in the literature include: (i) a smart, automated, flexible, physical production systems laboratory, (ii) an Industry 4.0 physical learning factory [10], (iii) an Industry 4.0 virtual learning factory [11], (iv) a virtual laboratory, and (v) a computing laboratory. An increasing rate of adopting information and communication technology (ICT) to support engineering education with an associated tendency to make teaching and learning more virtual has also been observed. Schuster et al. [10], in supporting this trend, argue that, since today's students are going to be working in Industry 4.0 contexts, it is important to immerse them in virtual learning environments (VLEs) for experience. The objective is to introduce students to experimentation, problem-solving, data-gathering, and scientific interpretation early in their programmes.

But while well-endowed institutions may find it affordable to create as many specialised lab units as they desire, for those who do not have the means to acquire comprehensive state-of-the-art facilities quickly, the growing complement of required practical-oriented learning facilities means that guidelines are needed on how to formulate a selection strategy to suit needs while defining a viable path toward Industry 4.0.

For example, at Perdue University in the USA, the IE department owns more than 12 separate labs [12]. Another is lowa State University, also in the USA, where the Industrial and Manufacturing Systems Engineering Department owns 13 separate teaching laboratory facilities [13]: an operation research and production systems lab, an industrial design lab, a computing lab, metrology, a machining processes lab, a metal casting lab, a cognitive and physiological engineering lab, an adaptive cognitive systems lab, an industrial assessments centre, an interdisciplinary manufacturing engineering and design lab, an industrial automation lab, a welding and robotics lab, and a rapid manufacturing and prototyping lab. The industrial design unit provides senior students with the opportunity to practice comprehensive engineering and communication skills while simultaneously honing their effectiveness skills through the development and completion of an industrial design project supplied by companies. The metrology unit contains a variety of advanced measuring and fixturing systems, including coordinate measuring machines, digital capture systems, a digital surface profilometer for measuring surface roughness, manual measuring tools, and modular fixturing systems. And the rapid manufacturing and prototyping unit, which has various rapid prototyping, reverse engineering, and computer-controlled manufacturing processes - including fused deposition - can be absorbed into a production systems lab or learning factory structure.

The IE Department at Texas Tech in the USA, for its part, maintains three separate labs in the area of ergonomics teaching and research - a general ergonomics lab, a biomechanics lab, and a work physiology lab - in addition to a computing facility: a human factors interfaces simulation lab [14].

In South Africa, recent studies on Industry 4.0 learning factories [8] [9] have revealed the preferences and future plans of IE departments for this kind of learning facility.

But are niche labs necessarily a good idea? And how many of these, and other types, and in what form, are needed to cater at least to undergraduate and diploma student teaching and learning needs in a holistic manner? For the not-so-well-endowed, the need is to develop a strategy that ensures an efficient use of scarce physical resources, while ensuring minimal abstraction [10] in these practical learning facilities. The purpose of this study is to evolve a framework of an industrial engineering practical learning infrastructure that reflects various levels of facility automation up to Industry 4.0, as a basis for optimising the use of resources through inbuilt flexibility in a regime that supports comprehensive instruction. 


\subsection{Survey results: Production systems laboratories and other physical learning facilities used}

A survey was carried out of ten South African universities to form a picture of what IE they currently offer on the subject in question. This sample took into account only those that offered IE as a discipline, and was analysed to identify trends and patterns and features of their practical instruction infrastructure, in particular in regard to the development of these kinds of facilities.

Table 1 displays information on the production systems laboratories used by IE departments in South Africa. A traditional university is designated with a number $1,2,3$, or 4 , while a technical university is denoted by $A, B, C, D, E$, or $F$, for identification purposes only, with no ranking in mind.

Table 1: Production systems laboratory in IE departments of ten South African universities

\begin{tabular}{|c|c|}
\hline $\begin{array}{c}\text { IE institution, } \\
\text { identification, and } \\
\text { type }\end{array}$ & Employs a production systems laboratory? Type? \\
\hline 1 & Yes (fixed) \\
\hline 2 & No response, and no indication in online curriculum \\
\hline 3 & $\begin{array}{c}\text { No, not any more. IE department used to have one, but it was never used. IE department now } \\
\text { uses mechanical engineering department facilities, if need be. }\end{array}$ \\
\hline 4 & Yes (under development, will be flexible, modular, and reconfigurable) \\
\hline A & Yes (fixed) \\
\hline B & Yes (fixed) \\
\hline C & Yes (fixed) \\
\hline E & Yes (fixed), soon to be commissioned \\
\hline F & No, due to lack of funding \\
\hline
\end{tabular}

1, 2, 3, 4: Traditional universities offering BEng IE

A, B, C, D, E, F: Technical universities offering ND or Dip/BTech IE

As can be seen, the table reveals that IE programmes in traditional and in technical universities differ sharply in their deployment of physical learning facilities beyond a computing lab, which all institutions possess. In all the technical universities, industrial engineering departments are positively disposed to operating a production systems laboratory (in fact, only one institution does not have one, due to a lack of funding support). On the other hand, none of the traditional university programmes, with the notable exception of one, has a production systems laboratory; nor do they plan to operate one in the near future. Three of the six technical or comprehensive universities retain fixed, inflexible labs, while a fourth has its lab under development. This pattern of preference in the traditional universities is exactly repeated in their orientation to Industry 4.0 learning factories. That only one programme in a traditional university had created an Industry 4.0 learning factory as of December 2016, and a second had elected to implement it in virtual or software terms only, has already been reported in a previous study [8]. Three of the six technical programmes might consider creating a physical learning factory in the future.

The survey results indicate that existing facilities are typically inflexible, while many traditional universities do not appear to have any immediate plans to establish such facilities, which could serve to motivate the need locally for a framework development and selection tool. Thus the results indicate that the research purpose of evolving a flexible IE facility framework as a guide to an Industry 4.0 learning factory in light of the current situation in IE departments in South Africa is a valid one.

\subsection{Conceptualisation of industrial engineering learning facility framework}

\subsubsection{A morphology of industrial engineering practical learning facility}

Figure 1 displays an IE learning facility morphology tree, depicting various facility types and reflecting various levels of automation. The structure provides a general morphology framework for IE learning facility characterisation, and has been informed by the literature review above and by a curriculum study of IE programmes in South Africa. Included in the structure are virtual systems and an Industry 4.0 learning factory (LF). A learning factory is a realistic model of a production environment that aims to bring the real world into the education environment through real-life projects, while a virtual laboratory is a computerbased interactive environment for creating and conducting simulations of engineering laboratory projects on a computer [15]. 
Each component facility would have its own individual didactic concept as part of the overall didactic concept for the structure. These individual models are the basis of the learning facility framework conceptualisation in this section.

In the facility framework of Figure 1, seven unique facility types can be identified. The ergonomics and adaptive cognitive systems lab is only representative of a wide range of specialised physical labs. The range and content of the different physical labs considered here have come from several sources [12] [13] [14]. Experience across the full spectrum of facility types, from manual systems to highly automated Industry 4.0 settings, would be much more likely to ensure success in holistic training than sticking to only a few of them, as was the case in some institutions [14].

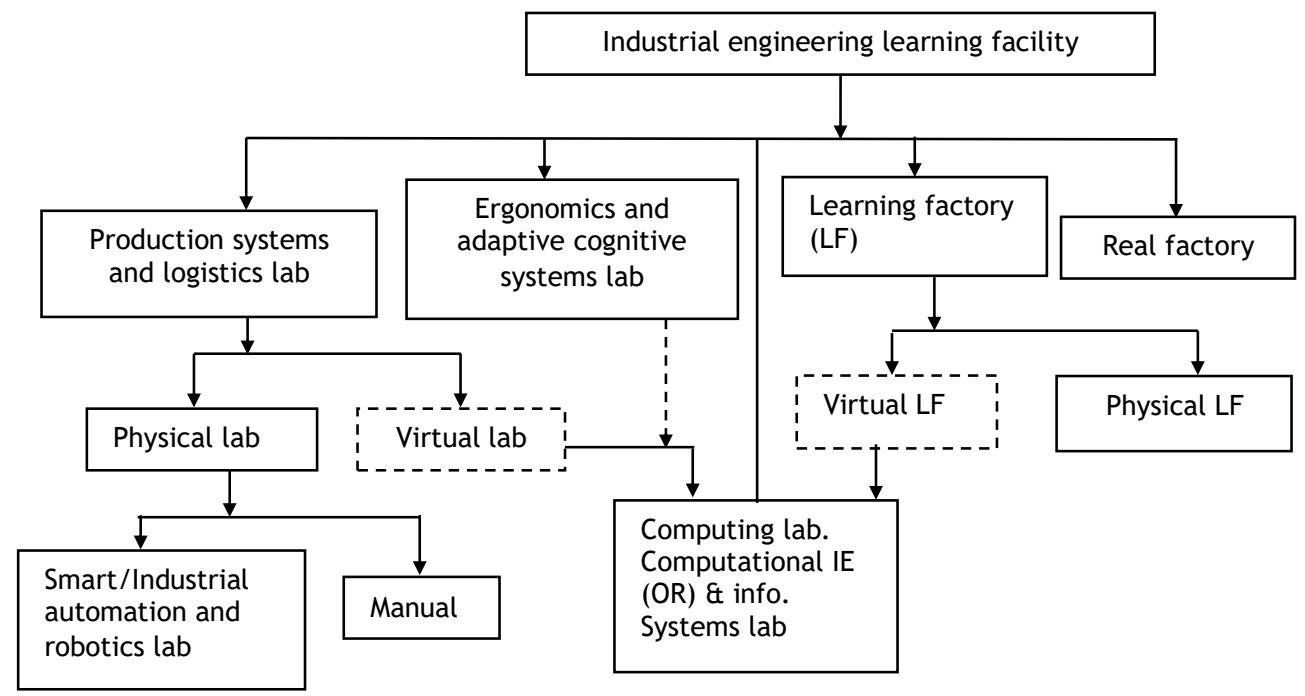

Figure 1: Industrial engineering learning facility framework

Table 2 casts the facility tree given in Figure 1 into a morphology table that highlights rationale and purpose, learning points, strengths, and weaknesses/limitations of various elements of the structure. An elaboration of these follows next.

\section{Physical production systems and logistics lab}

Within these facilities, the area of speciality included are; logistics and networks, production management, production planning and control, inventory control and management. Production systems research is performed and enhanced to focus on complex systems and networks. The purpose of manufacturing research within these labs is to to investigate the interplay between next-generation products and services. An automated version of this lab will feature robotics and would prepare students for working with basic AC/DC electrical circuits, as well as a variety of industrial sensors, bar code readers, RFID tags and readers, and Programmable Logic Controllers (PLCs). The lab equipment typically found may include RFID reader/programmer, 2D programmable bar code reader, PLCs with light sensors, a powered conveyor and pneumatic push-bars, transducer test board with over 40 different sensors and actuators, digital oscilloscope and voltmeter. Automatic storage and retrieval systems (AS/RS), sorting centre/systems, network platforms are among some of the production systems and logistics components commonly found in these labs. A major strength of these labs are that that they are able to show the demonstration of system elements connectivity.

\section{Virtual production systems and logistics lab}

The evolution of technology has made virtual labs possible and attractive, so widening the possibilities for teaching, learning, and connection. Their three fundamental dimensions are interactivity, symbolic flexibility, and a vast array of available information that can be used in experiments to capture countless what-if scenarios. 
Table 2: Purpose, characteristics, strengths, and weaknesses of various learning facilities in practical IE education

\begin{tabular}{|c|c|c|c|c|c|}
\hline \multicolumn{3}{|c|}{ Facility type } & Rationale / Purpose & Learning points & $\begin{array}{c}\text { Strengths / Weaknesses \& } \\
\text { limitations }\end{array}$ \\
\hline \multirow{3}{*}{ 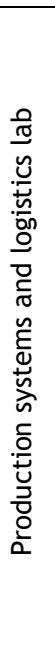 } & \multirow{2}{*}{$\frac{\pi}{\frac{0}{n}}$} & $\frac{\pi}{\stackrel{T}{D}}$ & $\begin{array}{l}\text { Low automation: } \\
\text { Undeveloped } \\
\text { facilities; basic \& } \\
\text { fundamental } \\
\text { concepts of IE }\end{array}$ & $\begin{array}{l}\text { Human ergonomics. Manual cycle } \\
\text { times \& lean systems, human work } \\
\text { study, line balancing. Production } \\
\text { planning, optimisation of manually } \\
\text { performed simple repetitive tasks, } \\
\text { traditional manual-intensive } \\
\text { statistical process control (quantity } \\
\text { required). Work study }\end{array}$ & $\begin{array}{l}\text { Human flexibility. Low cost } \\
\text { Fundamental concepts of IE } \\
\text { Not up to modernity. Low on } \\
\text { Industry 4.0. Limited in scope }\end{array}$ \\
\hline & & ڤั) & $\begin{array}{l}\text { High automation sys. } \\
\text { Modernity infused } \\
\text { Mimicking Industry } \\
4.0 \text { concepts short of } \\
\text { LF }\end{array}$ & $\begin{array}{l}\text { Automation basics } \\
\text { Human-robot collaboration Data } \\
\text { com., sensors } \\
\text { Computational IE } \\
\text { Mechatronics }\end{array}$ & $\begin{array}{l}\text { May incorporate some Industry } \\
4.0 \text { concepts. } \\
\text { The facility will have } \\
\text { computational capabilities } \\
\text { Obsolescence of system } \\
\text { components }\end{array}$ \\
\hline & $\stackrel{\frac{\pi}{2}}{\frac{\pi}{2}}$ & & $\begin{array}{l}\text { Cost effectiveness, } \\
\text { flexibility motive, } \\
\text { wide range of } \\
\text { subjects }\end{array}$ & $\begin{array}{l}\text { Computer-based } \\
\text { Interactive learning. } \\
\text { Collaborative platforms. } \\
\text { Simulations/lab projects } \\
\text { Computational IE } \\
\end{array}$ & $\begin{array}{l}\text { Cost effective. } \\
\text { High flexibility and range } \\
\text { Limitless scenario possibilities } \\
\text { Lacks real-touch }\end{array}$ \\
\hline \multicolumn{3}{|c|}{ 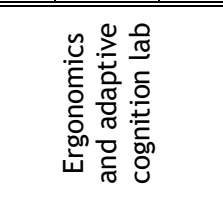 } & $\begin{array}{l}\text { A real setting for } \\
\text { human-based } \\
\text { experiments/ } \\
\text { measurements and } \\
\text { human-machine } \\
\text { interactions }\end{array}$ & $\begin{array}{l}\text { Human ergonomics, Anthropometry, } \\
\text { Work study, Adaptive automation } \\
\text { and interfaces, interactive learning } \\
\text { environments, and decision support } \\
\text { systems }\end{array}$ & $\begin{array}{l}\text { Novel concepts in human-robot } \\
\text { interaction can be investigated } \\
\text { Possible space } \\
\text { constraints/limitations }\end{array}$ \\
\hline \multicolumn{3}{|c|}{ 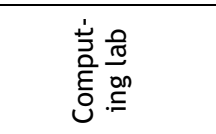 } & $\begin{array}{l}\text { Required as } \\
\text { minimum } \\
\text { Central computing } \\
\text { Reserve computing }\end{array}$ & $\begin{array}{l}\text { Computational IE. } \\
\text { Computer-based } \\
\text { experiments. }\end{array}$ & Lacks real-touch \\
\hline \multirow[b]{2}{*}{ 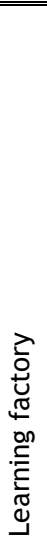 } & 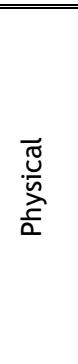 & & $\begin{array}{l}\text { Brings real world } \\
\text { into education } \\
\text { environment. } \\
\text { Practical hands-on } \\
\text { exposure }\end{array}$ & $\begin{array}{l}\text { Practical demonstration of } \\
\text { real-life projects } \\
\text { Real-time functions } \\
\text { Big data analytics } \\
\text { Human/machine interfaces } \\
\text { Digital to physical transfers }\end{array}$ & $\begin{array}{l}\text { Close to real-life setting for } \\
\text { demonstration of real-life } \\
\text { projects. } \\
\text { Practical hands-on experience. } \\
\text { Retains systems research } \\
\text { potential. } \\
\text { Initial cost may be high } \\
\text { Finding industry partners may } \\
\text { be tough. Lacks full company } \\
\text { culture }\end{array}$ \\
\hline & 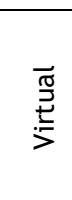 & & $\begin{array}{l}\text { Early introduction of } \\
\text { students to } \\
\text { concepts. } \\
\text { Possesses service } \\
\text { orientation. }\end{array}$ & $\begin{array}{l}\text { Expanded scope of experiments } \\
\text { Wider range of subjects learnt }\end{array}$ & $\begin{array}{l}\text { Cost-effective in long term. } \\
\text { High flexibility and range of } \\
\text { design problems. } \\
\text { May lack real-touch }\end{array}$ \\
\hline $\begin{array}{l}\frac{7}{0} \\
\stackrel{0}{0} \\
\frac{0}{0} \\
\frac{\pi}{\mathscr{d}} \\
\propto\end{array}$ & & & $\begin{array}{l}\text { Impartation of real } \\
\text { life experiences. } \\
\text { Blending theory with } \\
\text { practice. Exposure } \\
\text { to world of work \& } \\
\text { its organisational } \\
\text { culture }\end{array}$ & $\begin{array}{l}\text { What is learnt is dependent on } \\
\text { particular firm in question }\end{array}$ & $\begin{array}{l}\text { No substitute } \\
\text { Best opportunity to prepare } \\
\text { students to face real life } \\
\text { Little control over what is } \\
\text { learnt. Not designed with } \\
\text { student learning in mind. May } \\
\text { not teach some key concepts. } \\
\text { Student may not fit in. }\end{array}$ \\
\hline
\end{tabular}

\section{Ergonomics and adaptive cognitive systems and human performance lab}

These facilities mentioned in the morphology are for performing ergonomics investigations, design of joint human-technology collaborative systems in complex domains that adapt to the user, the environment, and the current situation. They facilitate a deeper understanding of the decision-making process. These 
performance labs provide novel human/machine interfaces. The focus here is aimed at human error, reliability and system safety as well as performance assessment (reaction time, performance time, learning time etc.). In the facility tree, this lab is only representative of a wide variety of physically specialised labs (refer to Section 3 above), most of which can also be implemented in the virtual mode, as shown in Figure 1.

Entities such as a metrology unit, a rapid manufacturing and prototyping unit, and an industrial design unit (as at the lowa state University, for example) can be absorbed into either the production systems and logistics lab or the learning factory structure; in this case, it is the latter.

\section{Computing lab}

In normal circumstances this computing facility would be the barest minimum for any IE department. The objective is to provide students with the appropriate equipment and software to develop analytical tools, algorithms, and heuristics that can advance their knowledge on the design and management of systems. The lab would contain relevant software with full internet connectivity. This lab could be distributed among the other physical facilities as needed, but there is always merit in maintaining it as a central facility. It would contain specialised mathematical and optimisation software, and make provision for operations research methodologies, production systems computing that encompasses optimisation, simulation, stochastic processes, and practical aspects of production planning, scheduling, inventory control, supply chains, and sustainable production systems.

\section{Industry 4.0 physical learning factory (a relatively new capability)}

A learning factory provides an industry-oriented education and training platform for students by attempting to show the links between theory and practice in a close-to-reality setting. It can be designed to demonstrate a wide collection of Industry 4.0 systems concepts, and could provide a platform for effective research collaboration with various industries. The LF could house industrial design, metrology, and rapid manufacturing and prototyping units that are equipped with the facilities that would provide senior students with the opportunity to practise comprehensive engineering, while honing their skills through developing and completing an industrial design project supplied by companies.

\section{Virtual learning factory}

A virtual learning factory offers the advantages of scalability, location-independence, and a wider scope of the problems addressed. As with a virtual production systems and logistics lab, the possibilities for learning and connection are greater, and the fundamental dimensions of interactivity, symbolic flexibility, and the vast array of available information for limitless what-if scenarios do still apply. Remote learning scenarios such as factory-to-classroom settings are also possible.

\section{Real factory}

This offers real-world industrial engineering practice, and provides opportunity for work-integrated learning. The arrangement is very well-developed in the National Diploma and Diploma Programmes in South Africa, but it must begin to anticipate Industry 4.0 concepts.

\subsubsection{Philosophy and broad design principles of IE learning facility morphology}

The cardinal design principle is that any adopted scheme must retain an inbuilt flexibility of structure [16] [1] to support practical learning experiences. These experiences cover a wide range of IE subjects and various levels of automation that are customised to suit the various levels of an IE qualification in both the traditional and technology tracks so that students can be given a broad and deep exposure to a wide range of traditional and contemporary IE concepts.

For any facility mix selection, relating especially to those in the lower-automation range, design principles promoting the flexibility of entities and systems for a physical production systems and logistics lab may include:

1. Work station disconnectibility (decoupling communication between workstations and the IT system in signal/message transmission as well as in physical connection terms)

2. Work station physical mobility [16]

3. Work station and system re-configurability and adjustability

4. Machine/process re-programmability

5. Line expandability (or extendibility), where work stations or units can be flexibly added to the production/assembly line 
This facility would consist of a shop floor area and an appropriately furnished seminar area. The flexibility in the structure would allow for future upgrading.

On the learning facility framework itself, the particular demonstrations and learning experiences that students require will dictate the specific structure of a particular facility mix that is selected. When starting off with a structure with minimal facilities, a good framework would be one that provides for progressive evolution from manual learning support systems to the usually highly automated Industry 4.0 learning factory. The morphology outlined above provides for further workstation upgrading with automation technology without disrupting the system significantly, to achieve (i) a flexible, smart, modular, and reconfigurable physical laboratory, or (ii) an automated, highly interconnected learning factory reflecting the fluid nature of Industry 4.0.

\section{DISCUSSION}

The IE learning facility morphology proposed in this paper is a basic generic framework that is neither unique nor static. Only the extremes of the facility continuum have been presented here. Facility mix selections could be made to suit particular needs.

In interpreting the results in Section 4, it can indeed be said that the IE facility framework presents us with a backdrop against which at least some physical learning facilities in IE departments in South Africa can be analysed. The inflexible production systems labs in several institutions seem to be out of tune with the flexibility of the proposed 'road map' framework. These fixed labs are therefore likely to add to the cost of maintaining current and up-to-date facilities, since they offer little scope for upgrading. Industrial systems are continuously developing and, to strengthen IE departments' capacity to respond to changing environments in a timely and cost-effective way, flexible learning facilities are needed. That all the production systems labs in relevant South African IE departments are inflexible validates the conclusion that flexible facilities are needed. Furthermore, the clear differentiation between the traditional and the technical programmes with regard to the deployment of some physical learning facilities would be captured by the IE facility framework, which could then be used to study and understand these differences for how they may develop in Industry 4.0 environments.

This work is different from previous research in several respects. The IE facility framework itself is a novelty. Other works have looked at specific lab or LF systems in a world or universal context, in many cases with no consideration of Industry 4.0; and whereas at least one group [16] previously promoted the flexibility idea, they did this for low-automation systems.

Since it is essential for IEs, especially those in the technology stream, to master basic industrial engineering hands-on methods, manual systems and related specialised labs are included in the structure to ensure that this happens (e.g., ergonomic design and anthropometric measurements and tools: noise, illumination, luminance, temperature measuring devices, weight, force measurements, strength measurement devices; and foot pressure, work physiology, etc.). Common to most diploma programmes is the idea that students have to assemble a real product, which involves carrying out all the planning steps normally required in the workplace. In the same vein, the facility structure rightly projects adaptive cognition systems as very important because of their relevance to Industry 4.0 systems. The goal is to develop design principles and practical guidelines to foster the development of collaborative systems that support human activity in complex domains, such as adaptive automation and interfaces, human/robot interaction, interactive learning environments, and decision support systems.

The learning factory concept supports a shift from a theoretical, lecture-based concept towards more active, hands-on, and student-centred courses, and ensures that problem-based learning is integrated into industrial engineering higher education. It helps in the cultivation of highly competent industrial engineers for global manufacturing. Its offer of hands-on experience provides the opportunity and motivation for students to test ideas and experiments in an environment that is close to an industrial setting. The smart IE laboratory could similarly be designed as a realistic environment and integrated into the teaching system. For students in the traditional stream, instrumentation for research manufacturing can be manufactured in a learning factory that, supported by computing capability, can then become a platform for exploration, application, discussion, reflection, and collaboration. It could serve as an aid for creative thinking in manufacturing, and for exploring new advanced manufacturing modes and concepts.

Virtual labs provide remote access in various disciplines of science and engineering. These labs would cater to IE students at the diploma, undergraduate, and post-graduate levels, and could inspire them to conduct 
experiments out of curiosity to investigate both basic and advanced concepts as part of a comprehensive connected learning system, which often must include additional web-resources such as video-lectures, animated demonstrations, and self-evaluation. They also help to reduce the cost of education and training.

A major advantage of the morphologic approach employed in this study, as a tool for describing the structure and hierarchy of IE learning facilities, is its inclusion of the relevant features, scenarios, characteristics, and potential strengths and limitations of each facility type. This projects a picture of the learning facility framework that is both holistic and generic, while at the same time permitting a particular facility type to be classified. This, then, enables a simplified analysis of the correlations between all existing options, and could certainly help in framing a strategy for the selection of a learning facility mix.

Whereas the generic nature of the facility framework might suggest an element of vagueness (i.e., a possible limitation), the seeming lack of specificity is not bad in itself, as it leaves room for customisation to suit particular needs. The framework itself provides for this modification or expansion to accommodate other models in the learning facility continuum. Likewise, the capabilities identified for each component IE facility could be expanded to cover specific situations. A strategy of progression is thus key to clarifying a path to the Industry 4.0 setting. This would seem a good response to those who have misgivings about learning factories on account of their lack of real-life company culture [6].

In operation, the user would apply the morphology tree to identify where they currently fit. They would then identify, with the help of Table 2, where they would like to be strategically (according to their purpose, strengths, and weaknesses), and then apply this as a basis for their strategic plan to develop learning facilities. This will state clearly the method of strategy implementation. Thus Table 2 is a useful framework that could be used as a platform to assess the strategic directions of an institution when looking at the different strengths and weaknesses of the various learning facilities.

\section{CONCLUSION}

Today's industrial engineers need cross-functional skills that will enable them to understand socio-technical work systems from an integrated and holistic point of view. Only then will they be able to identify and analyse problems and system improvement potentials, which is an essential element in the systematic problem-solving process to which they must bring core competences relating to methodology, systems, and problem-solving [16].

As a way to conclude this paper, the author now revisits the original motivation: the need to develop a strategy that ensures an efficient use of scarce resources because, as the functions and research areas expand beyond the borders of traditional IE approaches, the efficient use of resources within the South African tertiary education community becomes critical. A conclusion of the creation of this framework was that a full case was made outlining the place and benefits of each component in the full complement of facilities needed in the learning support infrastructure.

The survey conducted for this research showed that frustration with rapid technological change, which tends to render new facilities outdated far sooner than expected, may have played a role in some institutions losing interest in maintaining their physical facilities, and rejecting ideas for future smart facilities because rapid technological change outdates any plans that are made for new facilities. However, the ever-growing complement of required facilities means that guidance is needed to formulate a selection strategy to meet current and future needs, as well as to define a viable path toward Industry 4.0 in education.

In this paper, a comprehensive and unified framework has been proposed as a guide for developing and implementing a holistic learning facility strategy for industrial engineering education in South Africa; and therein lies its practical significance. While all the facility types discussed, including the learning factory, are existing models, the concept of an IE learning facility framework is not, as it shows both instructors and students the complexity of the interconnection of the virtual, digital, and real worlds that works to strengthen the systems and interfacing competence of students. The structure also provides a viable and useful framework that an institution could use to develop an appropriate learning facility strategy.

Further work could include the development of a tool to link the educational strategy/ priorities of an institution to appropriate learning facility models. Future research could also focus on how to evaluate success factors in the design and implementation of smart laboratories and learning factories. 
The authors gratefully acknowledge the Faculty of Engineering of the Cape Peninsula University of Technology, Cape Town, South Africa, for fully supporting this work.

\section{REFERENCES}

[1] Hermann M., Pentek T. \& Otto B. 2015. Design principles for industrie 4.0 scenarios: A literature review. Technical University, Dortmund. [Online] Available at:

http://www.snom.mb.tu-dortmund.de/cms/de/forschung/Arbeitsberichte/Design-Principles-for-Industrie-4_0Scenarios.pdf. Accessed: 04 January 2016.

[2] Kagermann, H., Wahlster, W. \& Helbig, J. 2013. Recommendations for implementing the strategic initiative Industrie 4.0: Final report of the Industrie 4.0 Working Group. [Online] Available at: http://www.acatech.de/fileadmin/user_upload/Baumstruktur_nach_Website/Acatech/root/de/Material_fuer_So nderseiten/Industrie_4.0/Final_report_Industrie_4.0_accessible.pdf. Accessed: 06 Janusary 2016.

[3] Rüßmann, M., Lorenz, M., Gerbert, P., Waldner, M., Justus, J., Engel, P. \& Harnisch, M. 2015. Industry 4.0: The future of productivity and growth in manufacturing industries. [Online] Available at: https://www.bcgperspectives.com/content/articles/engineered_products_project_business_industry_40_future_ productivity_growth_manufacturing_industries/. Accessed: 01 September 2015.

[4] Khaitan, S.K. \& McCalley, J.D. 2015. Design techniques and applications of cyber physical systems: A survey. IEEE Systems Journal, 9(2), pp. 350-365.

[5] Shead, S. 2013. Industry 4.0: The next industrial revolution, The Engineer, 11 July. [Online] Available at: http://www.theengineer.co.uk/manufacturing/automation/industry-40-the-next-industrialrevolution/1016696.article. Accessed: 10 December 2015.

[6] Baur, C. \& Wee, D. 2015. Manufacturing's next act. Insights and Publications. [Online] Available at: http://www.mckinsey.com/business-functions/operations/our-insights/manufacturings-next-act. Accessed: 05 January 2016.

[7] Lorenz, M., Rüßmann, M., Strack, R., Lueth, K.L. \& Bolle, M. 2015. Man and machine in Industry 4.0. September 28. Bcg Perspectives. [Online] Available at: https://www.bcgperspectives.com/content/articles/technology-business-transformation-engineered-productsinfrastructure-man-machine-industry-4/. Accessed: 08 December 2015.

[8] Sackey, S.M., Bester, A. \& Adams, D. 2017, Industry 4.0 learning factory didactic design parameters for industrial engineering education in South Africa, South African J. Ind. Eng., vol. 28(1), pp114-124.

[9] Sackey, S.M., \& Bester. A. 2016. Industrial engineering curriculum in Industry 4.0 in a South African context, South African Journal of Industrial Engineering, 27(4), pp 101-114.

[10] Schuster, K., Groß, K., Vossen, R., Richert, A. \& Jeschke, S. 2015. Preparing for Industry 4.0 - Collaborative virtual learning environments in engineering education. The International Conference on E-Learning in the Workplace (ICELW), June $10^{\text {th }}-12^{\text {th }}$, pp. 1-6, New York, NY, USA.

[11] Burger, S. 2015. Industry 4.0 requires factories of learning. Creamer Media Engineering News. [Online] Available at: http://www.engineeringnews.co.za/article/ industry-40-requires-factories-of-learning--festo-2015-0424/rep_id:4136. Accessed: 12 January 2016.

[12] School of Industrial Engineering, Perdue University. 2020. School of Industrial Engineering. [Online] Available at: https: //engineering.purdue.edu/IE. Accessed: 16 June 2017

[13] Industrial and Manufacturing Systems Engineering Department, lowa State University. 2020. Welcome to the IMSE Department! [Online] Available at: https://www.imse.iastate.edu/. Accessed: 16 June 2017.

[14] Industrial and Manufacturing Engineering, Texas Tech University. n.d. Industrial, Manufacturing \& Systems Engineering. [Online] Available at: http://www.depts.ttu.edu/ieweb/groups/aml/. Accessed: 16 June 2017.

[15] Edutech Wiki. 2019. The virtual laboratory. [Online] Available at: http://edutechwiki.unige.ch/en/Virtual_laboratory. Accessed: 28 June-2017.

[16] Steffen, M., May, D. \& Deuse, J. The industrial engineering laboratory. [Online] Available at: http://ieeexplore.ieee.org/stamp/stamp.jsp?arnumber=6201098. Accessed: 28 June 2017. 